\title{
Assessment of the Need for Human Resources in the Non-Humanitarian Sphere in the Economy of the Khabarovsk Territory on the Basis of Artificial Neural Networks
}

\author{
Luciena E. Piunko* Elena V. Tolkacheva
}

\begin{abstract}
Far-East Institute of management, branch of the Russian Presidential Academy of National Economy and Public Administration (hereinafter RANEPA), Department of mathematical methods and information technologies, Khabarovsk 680000, Russia

*Corresponding author. Email: lusiena_03@mail.ru
\end{abstract}

\begin{abstract}
The article is devoted to the study of the use of neural networks for analysis and forecasting of socio-economic processes, both in Russia and in its individual subjects, on the example of the Khabarovsk territory. The study was carried out by building neural networks to assess, analyze and forecast labor resources in Russia, in the far Eastern Federal district, and as a private aspect - in the Khabarovsk territory. Brief results of scientific analysis and evaluation of modern system of education in preparation of graduates in different clusters of the national economy made the Outlook for reducing the number of labor resources in Khabarovsk territory and the far Eastern Federal district, as threat trends for the effective development of Russia's Eastern territories. The conclusion about efficiency of application of neural networks for estimation of target indicators of the existing regional programmers aimed at education (teaching), employment promotion, support to fill manpower in science-related spheres of economy of the Khabarovsk territory, as well as improving the quality of education of the population to use modern information technologies in the framework of the digital economy, to create jobs in high-tech industries, development of popularization of technical and information-technical education for successful and effective redistribution of jobs for intensive development of the Eastern territories of the Russian Federation.
\end{abstract}

Keywords: digital economy, demographics, quality of life, neural networks, socio-economic processes, labor

market, information society

\section{INTRODUCTION}

In the context of the development of digital technologies, significant transformations are taking place in the professional sphere. New competencies are becoming popular among specialists in various sectors of the economy. At the regional level, programs are being adopted to modernize education so that society is ready for major information technology changes. At the same time, the relevant ministries and departments are faced with the task of not just modernizing the existing systems of economic and social development, but also organizing the training of the young generation so that the knowledge gained in the system of General and specialized education now (today) does not become outdated in the next ten or fifteen years.

The uncertainty generated by digital transformation is one of the reasons for the difficulties that arise in predicting the competencies that a professional (specialist) will need to possess in order to successfully implement production and management processes in the digital economy. This problem, in turn, is integrated into the broader problem of the demand for labor resources in the digital economy.

The problems of assessing the needs of the economy in labor resources have been studied in recent years by a number of authors and in various aspects. Thus, Moroz D. M., Astafieva M. P. and Pitukhin E. A. outlined the main problems of forecasting the number of employees in the economy, and also proposed their own method of forecasting [4]. Marien L. S. and Melnikova D. M. [3] considered the reasons and principles that determine the formation of new approaches to forecasting the needs of the Russian economy in qualified personnel in the conditions of digitalization. Pitukhin E. A., Kekkonen A. L., Shabaeva S. V. we studied the potential of the education system of the Far East from the position of ensuring the advanced development of the macroregion as a priority territory of Russia, and gave a forecast quantitative assessment of the educational system's capabilities to meet the needs of the economy of the Far East with personnel with secondary professional and higher education [5]. Okunkova E. A. proposed basic methods and tools for calculating the needs of the innovative economy in highly qualified personnel for the long and medium term [6]. Peshkova, G. Yu., Samarin, 
and $\mathrm{A}$. Yu. we have identified the problems that the digitalization policy in Russia faces or may face, and formulate acceptable solutions to them [7].

Also, a number of authors have studied and proposed several options for using neural networks in management activities. So Kashirina E. A. defines neural networks as the main tool for predicting indicators of socio-economic development. Motrin T. G., Demenko A., and Dolgov, I. V. describe the neural network as one of the main methods of forecast performance [8].

At the same time, the possibilities of using neural networks as a method for assessing and clustering labor needs in the Khabarovsk territory have not been studied. Thus, the purpose of this paper is to characterize the possibility of using neural networks to assess the needs for non-human labor resources in the economy of the Khabarovsk territory.

\subsection{Analysis of the number of able-bodied population of the Khabarovsk territory and the share of graduates of educational institutions by economic clusters region}

Through the use of neural networks, the analysis of the number of able-bodied population of the Khabarovsk territory and the share of graduates of educational institutions in clusters of the region's economy was carried out. Preliminary data of the official state statistics, on the basis of which the neural network was built, are given in this section.

\subsubsection{Intensive development of industrial production in Russia and shortage of labor resources in non-humanitarian areas of its economy}

Today, Russia is actively developing industrial production; from 2000 to the present. Many enterprises (hundreds or even thousands) in Russia during this period were either restored after the collapse, or modernized in such a way that enterprises produce products not only for the domestic market, but also for the foreign market (during 1990-2000, the situation was the opposite). If we analyse statistics ,for example, "Graduation of bachelors, specialists, and masters by higher education organizations and scientific organizations in groups of specialties and areas of training", we can see that the trend that began in the 1900s to train more and more "humanitarians" in the field of Humanities, economic Sciences, management, culture and art, and the service sector is steadily growing, the authors do not want to beg the significance of these areas for the country's economy and society, but in the last fifteen or twenty years, and most importantly in the coming decades should increase the trend in technical environments and in the healthcare environment, taking baseline "economy and management", we have calculated the ratio to it of the other areas of training, due to the fact that the values for the number of graduates of the direction "economy and management are the highest in the whole table Rosstat, the second largest number of graduates belongs to the "Humanities" (table 1).

\subsubsection{Estimation of the share of the working age population in the Khabarovsk territory and in Russia.}

The proportion of the working age population in the Khabarovsk territory is higher than in Russia in General and in the far Eastern Federal district, and this population tends to outflow from the Khabarovsk territory and the DFO, which is critical for the future development of these territories.

Table 2 shows the total number of able- bodied people.

\subsubsection{Estimation of the share of specialists with higher education employed in socially significant areas of the region's economy.}

We see that in the Khabarovsk territory, as well as in the far Eastern Federal district, there is a tendency to reduce the number of workers. Over the past 18 years, the labor force in the Khabarovsk territory has decreased by $5.4 \%$, which is lower than the rate of decline in the labor force in the far Eastern Federal district (9.2\%). However, it should be taken into account that in the Russian Federation as a whole, the labor force has increased by 4.3 percent over the past 18 years.

The low percentage of specialists with higher education employed in socially significant areas of education and health care for such large territories as the far Eastern Federal district and the Khabarovsk territory is also a factor affecting the outflow of population (table 3).

\subsubsection{Preliminary conclusions on the assessment of the need for personnel that exists in the economy of the Khabarovsk territory.}

In the current conditions, the issues of assessing the need for personnel, which exists in the economy of the Khabarovsk territory, by the system of professional education in the context of professions and specialties/ areas of training, are updated. It is important to understand how many graduates the system should prepare for the levels of education in order to meet the staffing needs of the region's economy, while taking into account the clusters of the labor market [4]. 
Table 1 Graduation of bachelors, specialists and masters of educational institutions of higher professional education and scientific institutions in groups of specialties and areas of training (thousands of people)

\begin{tabular}{|c|c|c|c|c|c|c|c|}
\hline Sphere of economy & 2010 & 2014 & 2015 & 2016 & $\begin{array}{l}\text { Percentage of } \\
\text { graduates in this } \\
\text { field in } 2016 \text { to } \\
2010\end{array}$ & \begin{tabular}{|c|} 
Growth rate \\
in 2016 \\
compared to \\
the base year \\
$2010 *$
\end{tabular} & $\begin{array}{c}\text { Percentage of } \\
\text { graduates of } \\
\text { "Economics and } \\
\text { management " in } \\
20166^{* *}\end{array}$ \\
\hline $\begin{array}{l}\text { Issued bachelors, specialists, masters- } \\
\text { total }\end{array}$ & 1178 & 1018 & 1301 & 1161 & $99 \%$ & $-1 \%$ & \\
\hline \multicolumn{8}{|c|}{ including groups of training areas and specialties: } \\
\hline Physical and mathematical Sciences & 16,5 & 15,4 & 19,7 & 15,4 & $93 \%$ & $-7 \%$ & $4 \%$ \\
\hline Natural science & 16,7 & 17,6 & 23,0 & 19,6 & $117 \%$ & $17 \%$ & $6 \%$ \\
\hline Humanities & 192,5 & 158,0 & 261,1 & 244,8 & $127 \%$ & $27 \%$ & $69 \%$ \\
\hline Social Sciences & 18,2 & 16,8 & 19,0 & 14,3 & $79 \%$ & $-21 \%$ & $4 \%$ \\
\hline Education and pedagogy & 125,5 & 96,9 & 100,8 & 93,6 & $75 \%$ & $-25 \%$ & $26 \%$ \\
\hline Health & 33,3 & 35,9 & 35,4 & 38,4 & $115 \%$ & $15 \%$ & $11 \%$ \\
\hline Culture and art & 19,7 & 20,6 & 27,6 & 25,2 & $128 \%$ & $28 \%$ & $7 \%$ \\
\hline Economy and management & 408,8 & 331,0 & 419,2 & 356,2 & $87 \%$ & $-13 \%$ & $100 \%$ \\
\hline Information security & 3,6 & 3,5 & 5,3 & 4,0 & $111 \%$ & $11 \%$ & $1 \%$ \\
\hline Service sector & 14,5 & 14,7 & 26,6 & 25,2 & $174 \%$ & $74 \%$ & $7 \%$ \\
\hline Agriculture, forestry and fisheries & 36,7 & 32,1 & 45,6 & 40,1 & $109 \%$ & $9 \%$ & $11 \%$ \\
\hline Geodesy and land management & 5,7 & 6,4 & 9,0 & 8,1 & $142 \%$ & $42 \%$ & $2 \%$ \\
\hline $\begin{array}{l}\text { Geology, exploration and development } \\
\text { of minerals }\end{array}$ & 15,4 & 17,5 & 17,7 & 15,1 & $98 \%$ & $-2 \%$ & $4 \%$ \\
\hline $\begin{array}{l}\text { Energy, power engineering and } \\
\text { electrical engineering }\end{array}$ & 29,4 & 29,3 & 33,8 & 33,1 & $113 \%$ & $13 \%$ & $9 \%$ \\
\hline $\begin{array}{l}\text { Metallurgy, mechanical engineering } \\
\text { and material processing }\end{array}$ & 28,4 & 23,3 & 26,2 & 25,4 & $89 \%$ & $-11 \%$ & $7 \%$ \\
\hline $\begin{array}{l}\text { Aviation and rocket and space } \\
\text { technology }\end{array}$ & 5,9 & 5,4 & 5,4 & 5,1 & $86 \%$ & $-14 \%$ & $1 \%$ \\
\hline Weapons and weapons systems & 0,6 & 0,4 & 0,3 & 0,2 & $33 \%$ & $-67 \%$ & $0 \%$ \\
\hline Marine engineering & 4,4 & 4,2 & 4,4 & 4,9 & $111 \%$ & $11 \%$ & $1 \%$ \\
\hline Means of transport & 35,8 & 33,8 & 36,7 & 33,0 & $92 \%$ & $-8 \%$ & $9 \%$ \\
\hline Instrumentation and optoelectronics & 9,3 & 7,7 & 7,8 & 5,3 & $57 \%$ & $-43 \%$ & $1 \%$ \\
\hline $\begin{array}{l}\text { Electronic engineering, radio } \\
\text { engineering and communications }\end{array}$ & 18,2 & 15,2 & 16,6 & 13,6 & $75 \%$ & $-25 \%$ & $4 \%$ \\
\hline Automation and control & 16,6 & 16,5 & 21,6 & 19,3 & $116 \%$ & $16 \%$ & $5 \%$ \\
\hline Computer science and engineering & 26,7 & 27,0 & 40,4 & 35,2 & $132 \%$ & $32 \%$ & $10 \%$ \\
\hline Chemical and biotechnology & 12,8 & 10,2 & 13,4 & 11,6 & $91 \%$ & $-9 \%$ & $3 \%$ \\
\hline $\begin{array}{l}\text { Reproduction and processing of forest } \\
\text { resources }\end{array}$ & 6,7 & 5,5 & - & - & $0 \%$ & $-100 \%$ & $0 \%$ \\
\hline $\begin{array}{l}\text { Technology for food and consumer } \\
\text { products }\end{array}$ & 19,2 & 16,0 & 17,7 & 15,0 & $78 \%$ & $-22 \%$ & $4 \%$ \\
\hline Architecture and construction & 43,0 & 43,0 & 50,2 & 45,9 & $107 \%$ & $7 \%$ & $13 \%$ \\
\hline $\begin{array}{l}\text { Life safety, environmental } \\
\text { management and environmental } \\
\text { protection }\end{array}$ & 13,9 & 11,6 & 15,9 & 13,5 & $97 \%$ & $-3 \%$ & $4 \%$ \\
\hline
\end{tabular}


Table 2 Number of employees (thousands of people)

\begin{tabular}{|c|c|c|c|}
\hline \multirow{2}{*}{ Years } & \multicolumn{2}{|c|}{ 15-72 years old } & Khabarovsk territory \\
\cline { 2 - 4 } & Russian Federation & Eastern federal district & 765,2 \\
\hline 2000 & 72769,9 & 3628,2 & 738 \\
\hline 2001 & 71546,6 & 3513,4 & 738,5 \\
\hline 2002 & 72357,1 & 3487,7 & 750,9 \\
\hline 2003 & 72273 & 3535,9 & 747,6 \\
\hline 2004 & 72984,7 & 3493,3 & 755,5 \\
\hline 2005 & 73581 & 3454,2 & 729,8 \\
\hline 2006 & 74418,9 & 3454 & 761,7 \\
\hline 2007 & 75288,9 & 3463,7 & 740,2 \\
\hline 2008 & 75700,1 & 3517,4 & 743,3 \\
\hline 2009 & 75694,2 & 3483,1 & 750,8 \\
\hline 2010 & 75477,9 & 3437,2 & 745,6 \\
\hline 2011 & 75779 & 3459 & 746,8 \\
\hline 2012 & 75676,1 & 3427,2 & 744,6 \\
\hline 2013 & 75528,9 & 3434 & 727,9 \\
\hline 2014 & 75428,4 & 3412,4 & 734 \\
\hline 2015 & 76587,5 & 3376,3 & 733,1 \\
\hline 2016 & 76636,1 & 3355,5 & 725,8 \\
\hline 2017 & 76108,5 & 3339,6 & 3323,2 \\
\hline 2018 & 76011,4 & 30 . & \\
\hline
\end{tabular}

a. Official website of the Russian state statistics "Official statistical indicators" [Electronic resource] / [ access mode]:https://www.fedstat.ru/indicator/34061 [11]

Table 3. The number of jobs for all types of work on the production of goods and services (on average per year) since 2017 in the Khabarovsk territory (units)

\begin{tabular}{|l|c|c|}
\hline \multicolumn{1}{|c|}{ Types of work for the production of goods and services } & $\mathbf{2 0 1 7}$ & 888512 \\
\hline Total by type of economic activity surveyed & 876348 & 175970 \\
\hline Agriculture, forestry, hunting, fishing and fish farming & 167861 & 12999 \\
\hline Activities in the field of information and communication & 12653 & 59920 \\
\hline Education & 60450 & 14932 \\
\hline Financial and insurance activities & 14149 & 60767 \\
\hline Public administration and military security; social security & 60586 & 2785 \\
\hline $\begin{array}{l}\text { Activities of households as employers; undifferentiated activities of private households to produce goods } \\
\text { and provide services for their own consumption }\end{array}$ & 6695 & 6763 \\
\hline Water supply; water disposal, waste collection and disposal, pollution elimination activities & 6516 & 66691 \\
\hline Transportation and storage & 65811 & 81582 \\
\hline Construction & 79481 & 25589 \\
\hline Professional, scientific and technical activities & 26458 \\
\hline Real estate operations & 17828 & 21592 \\
\hline Provision of electricity, gas and steam; air conditioning & 22085 & 20578 \\
\hline Providing other types of services & 14439 & 13522 \\
\hline Activities of hotels and catering establishments & 20121 & 19460 \\
\hline Manufacturing activity & 76492 & 79344 \\
\hline Activities in the field of health and social services & 50430 & 50360 \\
\hline Administrative activities and related additional services & 21892 & 22241 \\
\hline Activities in the field of culture, sports, leisure and entertainment & 12201 & 12219 \\
\hline Wholesale and retail trade ; repair of motor vehicles and motorcycles & 129387 & 130064 \\
\hline Extraction of minerals & 10813 \\
\hline
\end{tabular}

a. Official website of the Russian state statistics "Official statistical indicators" [Electronic resource] / [ access mode]: HTTP://OLD.GKS.RU/WPS/WCM/CONNECT/ ROSSTAT_MAIN/ROSSTAT/RU/STATISTICS/PUBLICATIONS/CATALOG/DOC_1139916801766 [11] 


\subsection{Artificial neural networks as a modern tool for analyzing and predicting socio-economic processes in the digital economy}

Artificial neural networks are one of the most promising tools for predicting socio-economic indicators. They open up new approaches to the study of dynamic systems in the field of Economics. The mechanism of functioning of neural networks assumes that a system of connected and closely interacting fairly simple processors (artificial neurons) is essentially an artificial neural network.

The main advantage of neural networks over traditional computational algorithms is the ability to learn. From a technical point of view, training consists in finding the coefficients of connections between neurons.

In General, the difference between neural networks and traditional forecasting models consists in taking into account a large amount of information, which increases the accuracy of the forecast. The accuracy of a one-year forecast made using neural networks can be more than $90 \%$. At the same time, the need to use neural networks in the economic field is not due to replacing traditional methods. The goal of data mining is to identify latent patterns and rules in data sets.

At the same time, the model of the process of assessing the need for human resources in the non-humanitarian sphere in the economy of the Khabarovsk territory based on artificial neural networks may include a number of elements:

1. The input values of indicators such as the number of jobs for specific type of works for the production of goods and services (Table 3), labour force (according to Table 2), the number of places by groups of specialties and areas of training in educational institutions of higher education in Khabarovsk territory.

2. The output is a classification sign indicating the need to reduce or increase the number of seats in the educational institutions of higher education.

3. Limitations of the process of assessing the need for labor resources - the reliability of the output data within 0.05 .

4. Providing mechanisms - software used to assess the need for labor resources, a mathematical model of a neural network. Limitations of the process of assessing the need for labor resources - the reliability of the output data within 0.05 .

A similar model can be used to assess the labor needs of non-humanitarian secondary vocational education.

\subsection{Our Contribution}

When building a neural network to assess the prognostic value of labor in terms of number of population permanently residing on the territory of Khabarovsk territory and far Eastern Federal district, was the result of a significant reduction in the number as the permanent population and workforce. This reflects the negative trends of the last thirty years of population outflow from the Far East and from the Khabarovsk territory, in particular.
Therefore, the measures that the Russian Government is taking today to preserve the permanent population in the East of the country, including in the Khabarovsk territory, are not enough to not only preserve the region's population, but also increase it.

\subsection{Paper Structure}

The rest of the article is organized as follows. Section 2 presents the preliminary data used in this article, which includes the final result of building a neural network for estimating the forecast of labor demand in the Khabarovsk territory, based on the above analysis and evaluation of state statistics data. An assessment of the current legislation on the development of the digital economy in Russia and its aspects in relation to the number of economically active population of the far Eastern Federal district and its constituent part - the Khabarovsk territory is made. Finally, at the end of the work, the main conclusions and direction for future research are presented.

\section{CONNECTION OF PROGRAMS FOR THE DEVELOPMENT OF THE DIGITAL ECONOMY IN RUSSIA AND PLANNING TRAINING FOR NON-HUMANITARIAN SECTORS OF THE ECONOMY OF THE KHABAROVSK TERRITORY}

Further, considering the programs for the development of the digital economy in Russia and the far Eastern Federal district, in particular; legislation in the development of the education system in Russia (including the decree Of the government of the Russian Federation of 26.12.2017 1642 " on approval of the state program in the Russian Federation "development of education" [9]), competence approach and transition to a professional standard, conclusions were drawn: the task of the relevant ministries and departments is not just to modernize the existing systems of economic and social development, but to prepare the young generation from the position of education so that the knowledge obtained in the system of General and specialized education now (today) is not outdated in the nearest ten - fifteen year perspective. I. e. it is necessary to develop standards, programs, and forms that include not just modern information technologies, but information technologies that will only be introduced into public life in the next ten or fifteen years. In the analysis of the education system, neural networks can significantly help, first of all, to identify factors that significantly affect the development of education in the country $[1,2]$.

\subsection{Analysis of the constructed neural network based on official statistics}

The task of developing modern programs and standards that prepare future specialists ahead of the curve, which allows 
creating specialists from modern students who are able and ready for self - study and self-education, is complex in its development, because it is connected with modern social challenges, the established model of moral and ethical principles, psychology and mentality of the modern young generation. In addition, the state is trying to reach the entire population as part of the modernization of education and training (retraining) of modern specialists. This gives rise to the target program of retraining of specialists of the older generation (especially before retirement age).

In modern realities, the government of the Russian Federation is developing education and health programs that include components "ahead of" their development in the near future, including the "Digital economy".

An attempt is being made to revive the importance of working professions, and correct the "kinks" in the education and training system in the period 1995-2010, when a significant part of graduates of General education institutions chose the future profession of "economist", "Manager" or "lawyer"; and the labor market in Russia today is oversaturated with these professions, and there is an acute shortage of specialists in "technical", "engineering" specialties, as well as doctors and medical workers, and this shortage extends in severity from West to East. Today, the far Eastern Federal district is experiencing an acute shortage of technical specialists, despite the fact that the size of the territory is a third of the entire Russia.

At the same time, the integration of the modern education system with the requirements and expectations of managers of industrial enterprises for the skills and abilities of specialists and employees, in our opinion, should take into account:

1) the requirements of professional standards themselves;

2) dynamics of changes in the labor market;

3) to preserve the best traditions and methods of the national education system (including, as the experience of the Russian Empire - Zemstvo schools; the rich experience of the Soviet period of the country, including professional and secondary special education);

4) to form a more scientific content of the subjects and disciplines studied in the system of General, secondary and higher education;

5) special attention in the education system should be paid to the disciplines of the natural science cycle (physics, chemistry, biology, mathematics, and information technology);

6) to give creation in the socio-cultural environment respectful attitudes to trades and to the professions of social sphere, perhaps even at the expense of a slight infringement of professions related to Commerce and trade, at the same time, for the profession of the seller (trade hall) or the cashier does not have to have a College education, because the nature and quality of this profession is not commensurate with the labour doctor, engineer, etc.; and for the profession of merchandise (expert) required special knowledge of markets, materials and raw materials for the manufacture of quality products; etc. this issue needs to be approached with reflection and selectively;
7) in the higher education system, provide motivation in the training of technical and engineering specialists, especially in the training of physical and mathematical specialists, chemists and biologists, including integrated areas (physical chemistry, biochemistry, etc.), allocating a greater number of budget places and places for the target set of these specialties.

\subsection{Results of the study}

1) The purpose of the above proposals is to balance the labor market so that there is no shortage or surplus of specialists in different sectors. There are a lot of employees with the specialty "economist", "Manager", "lawyer" in Russia today, so people have to either retrain for new specialties, or take jobs with lower qualifications than they have in their diploma.

2) Of course, knowledge in the field of law and Economics is necessary for every citizen of Russia, and the more literate the population is in these areas, the better it will be for the country as a whole. But when there are not enough specialists in the Russian Federation-engineers, physicists, chemists, biologists of various fields and related specializations, doctors, teachers-this problem must be solved. Regarding teaching: the teacher, as a specialist with a deep knowledge of the disciplines that he teaches, must also know the teaching methodology perfectly; teaching is not only a teacher's lectures to his students, in which he explains the material in a comprehensive and multifaceted way, but also the ability to build feedback with students, demand the study of the material, conduct quality control of knowledge. not every specialist in his field is able to be a teacher, just as not every medical worker is able to be a doctor.

3) Then, the use of traditional forecasting models is very difficult to assess the personnel reserve, as well as to analyze and evaluate the number of specialists prepared by the education system for economic clusters, because such analysis and forecasting are multi-factor and consists in taking into account a large amount of information, and therefore require increased accuracy of the forecast. The difference between neural networks is that they are able to perform multi-factor analysis and forecasting, taking into account a large amount of information, the accuracy of the forecast is very high at the same time more than $90 \%$, moreover, modern software tools allow you to quickly build neural networks. In other words, the use of neural networks is effective for qualitative analysis and forecasting of complex socio-economic models, and is economically feasible in comparison with traditional means of analysis (time series, variance analysis, etc.).

4) The measures that the Russian government is taking today to preserve the permanent population in the East of the country, including in the Khabarovsk territory, are not enough to not only preserve the region's population, but also increase it. 
practice and analysis. 2017. No. 4 (110). [Electronic resource] / [access Mode]:

https://cyberleninka.ru/article/n/prognozirovaniepotrebnostey-ekonomiki-v-kvalifitsirovannyh-kadrahobzor-podhodov-i-praktik-primeneniya (accessed 25.02.2020).

[6] Okunkova Elena Aleksandrovna Strategic foresight of personnel needs of innovative development of social and economic systems / / Management. 2019. No. 1. [Electronic resource] / [access Mode]: https://cyberleninka.ru/article/n/strategicheskiyforsayting-kadrovyh-potrebnostey-innovatsionnogorazvitiya-sotsialno-ekonomicheskih-sistem (accessed 25.02.2020).

[7] Peshkova G. Yu., Samarina A. Yu. Digital economy and personnel potential: strategic relationship and prospects / / Education and science. 2018. No. 10. [Electronic resource] / [access Mode]:

https://cyberleninka.ru/article/n/tsifrovaya-ekonomikai-kadrovyy-potentsial-strategicheskaya-vzaimosvyaz-iperspektivy (accessed 25.02.2020).

[8] Sichinsky Evgeny Pavlovich, Stashkevich Irina Rizovna Forecast of needs for qualified personnel for the digital economy of the region / / Innovative development of professional education. 2019. No. 2 (22). [Electronic resource] / [access Mode]: https://cyberleninka.ru/article/n/ prognoz-potrebnosteyv-kvalifitsirovannyh-kadrah-dlya-tsifrovoy-ekonomikiregiona (accessed 25.02.2020).

[9] Resolution Of the government of the Russian Federation of 26.12.2017 No. 1642 " on approval of the state program in the Russian Federation "Development of education" " in the ed. of 22.02.2020 No. 204 [electronic resource "Consultant Plus"] / [access Mode]: http://www.consultant.ru/document/ cons_doc_LAW_286474/

[10] Official website of the Russian state statistics [Electronic resource] / [access Mode]: http://old.gks.ru/wps/wcm/connect/ rosstat_main/rosstat/ru/statistics/publications/catalog/do c_1139916801766 (accessed 24.02.2020).

[11] Official website of the Russian state statistics "Official statistical indicators" [Electronic resource] / [access Mode]: https://www.fedstat.ru/indicator/34061 (accessed 25.02.2020)
[5] Gurtov Valery Alekseevich, Pitukhin Yevgeny Alexandrovich Forecasting the needs of the economy in qualified personnel: a review of approaches and practices of application / / University management: 